\title{
The instructional theory framework appears lost. Isn't it time we find it again?
}

\section{El marco de la teoría de la instrucción parece perdido ¿No es hora de que lo encontremos de nuevo?}

\author{
Peter C. Honebein ${ }^{1}$ \\ Indiana University, Bloomington, IN, USA \\ phonebei@indiana.edu \\ Charles M. Reigeluth \\ Indiana University, Bloomington, IN, USA \\ reigelut@indiana.edu
}

\begin{abstract}
Most researchers who design innovative digital learning experiences, and then conduct research that investigates the usefulness of those learning experiences, fail to fully apply the instructional theory framework (Reigeluth, 1983, 1999; Reigeluth \& Carr-Chellman, 2009a) as the foundation of their designs and the focus of their research. This choice negatively impacts researchers' design judgment (Boling, et al. 2017) and their credibility as the guarantor of design (Stolterman \& Nelson, 2000). This ultimately leads to diffusion barriers when disseminating their digital learning innovations. The purpose of this paper is to help researchers and learning-experience designers overcome these diffusion barriers by embracing the instructional theory framework as the foundation for their designs and using six principles for conducting research aligned with the framework: (1) Know complex systems qualitatively, (2) Value the treatment design fundamentals, (3) Practice unbiased consideration of instructional methods, (4) Respect the instructional design iron triangle, (5) Differentiate between methods and media, and (6) Know your personal instructional design theory.

Keywords: Instructional Theory, Instructional Methods, Design Research, Complex Systems, Design Judgment

\section{Resumen}

La mayoría de los investigadores que diseñan experiencias innovadoras de aprendizaje digital y luego realizan investigaciones que investigan la utilidad de esas experiencias de aprendizaje, no aplican completamente el marco de la teoría de la instrucción (Reigeluth, 1983, 1999; Reigeluth y Carr-Chellman, 2009a) como la base de sus diseños y el foco de su investigación. Esta elección afecta negativamente el juicio de diseño de los investigadores (Boling, et al. 2017) y su credibilidad como garantes del diseño (Stolterman y Nelson, 2000). Esto finalmente conduce a barreras de difusión cuando se difunden sus innovaciones de aprendizaje digital. El propósito de este documento es ayudar a los investigadores y diseñadores de experiencias de aprendizaje a superar estas barreras de difusión al adoptar el marco de la teoría de la instrucción como base para sus diseños y utilizar seis principios para realizar investigaciones alineadas con el marco: 1) Conocer los sistemas complejos cualitativamente, 2 ) Valorar los fundamentos del diseño del tratamiento, 3) Practicar una consideración imparcial de los métodos de instrucción, 4) Respetar el triángulo de hierro del
\end{abstract}

${ }^{1}$ Contact Information

Peter C. Honebein

peter@honebein.com | phonebei@indiana.edu

775-846-0398

RED. Revista de Educación a Distancia. Núm. 64, Vol. 20. Artíc. 1, 30-09-2020

DOI: http://dx.doi.org/10.6018/red.405871 
diseño de instrucción, 5) Diferenciar entre métodos y medios, y 6) Conocer su teoría de diseño de instrucción personal.

Palabras clave: Teoría de la instrucción, Métodos de instrucción, Investigación de diseño, Sistemas complejos, Juicio de diseño

\section{Introduction}

Most researchers who design innovative digital learning experiences, and then conduct research that investigates the usefulness of those learning experiences, fail to fully apply the instructional theory framework (Reigeluth, 1983, 1999; Reigeluth \& Carr-Chellman, 2009a; Reigeluth, Beatty, \& Myers, 2017) as the foundation of their methodological designs. This omission negatively impacts perceptions about researchers' design judgment (Boling, et al. 2017) and their credibility as the guarantor of design - which reflects a designer's "capacity to make good judgments" (Stolterman \& Nelson, 2000, p. 8). This reduces the usefulness of their research and ultimately leads to diffusion barriers when disseminating their advances in knowledge about digital learning.

Our purpose in writing this paper is to help researchers improve the usefulness of their research and reduce the diffusion barriers that impact the dissemination and adoption of their advances in knowledge about digital learning experiences. The sections of this paper include:

- Instructional Theory as a Framework for Research

- The Instructional Theory Framework

- The Instructional Theory Framework is Lost

- Researchers Must Find the Instructional Theory Framework and Apply It Overtly through Six Research Principles

- Conclusion

Formally linking instructional design and research to the instructional theory framework and its related design principles enables researchers to answer questions about the relative advantage, compatibility, complexity, observability, and trialability of their innovations (Rogers, 2003).

\section{Instructional Theory as a Framework for Research}

In the mid-1950s, at an Army base near Augusta, Georgia, four researchers, Joseph Kanner, Sanford Katz, William Mindak, and Peter Goldsmith, were conducting research into television's efficacy for delivering instruction to learners. The content? How to "install, operate, and [maintain] portable electric-generating equipment" (Kanner, Katz, Mindak, \& Goldsmith, 1958 , p. 256). The incumbent solution the team was researching was the first week of a 38-hour Power Maintenance course, a classroom experience that blended lecture, training films, and hands-on practical exercises. The alternative solution was a television course the researchers designed based upon the same instructor guide as the classroom course and for the same duration-38 hours. During the week-long experiment comparing the Classroom Instruction and Television Instruction groups, instructors administered tests twice a day, before lunch and at the end of the day. One month later, instructors administered a retention test associated with the first week's content.

The researchers evaluated the treatments across the outcome dimensions of effectiveness, efficiency, and appeal (Reigeluth \& Frick, 1999; Reigeluth \& Carr-Chellman, 2009a). Results associated with effectiveness showed that for immediate testing, the Classroom Instruction group

The instructional theory framework appears lost. Isn't it time we find it again? Peter C. Honebein \& Charles M. Reigeluth. 
had superior performance compared to the Television Instruction group. However, when it came to the retention testing, there was no significant difference between the Classroom group and the Television group. Results associated with efficiency showed time and cost savings benefits associated with the Television group. And finally, results associated with appeal showed increased boredom and low motivation in the Television group.

Based on these results, Kanner et al. (1958) conducted a second study with the same Power Maintenance course. In this study, their focus was improving efficiency and appeal of the television course while making formative changes to increase effectiveness. The study compared the 38-hour instructor-led course, a 38-hour revised televised course that enhanced various instructional methods, and three 16-hour courses (experienced instructor, inexperienced instructor, and kinescopes) that were further reductions of the 38-hour revised televised course specifically designed to assess the balance of efficiency and effectiveness.

As expected, there was no effectiveness difference between the two 38-hour treatments in both the immediate tests and retention tests. This was due to the improved instructional methods for the revised televised course. The 16-hour treatments had lower effectiveness on the immediate and retention tests. However, in terms of "washouts" (students dropped from the courses for not attaining mastery), there were no significant differences among all five treatments.

As for efficiency, the researchers demonstrated that they could reduce training time and costs while still achieving mastery comparable to the incumbent approach. As for appeal, there was no systematic collection of learner attitudes. However, the researchers' observations of the five learning experiences suggested that the 38 -hour solutions remained dull and boring, while the 16-hour solutions, with their 30-minute lessons and improved instructional techniques focused on reducing cognitive load, appeared to enhance learner endurance and attention.

For us, the Kanner et al. (1958) research is an exemplar that represents the spirit of an instructional theory framework that Reigeluth and Carr-Chellman (2009a) articulated 50 years later. In this early study there was a group of learning-experience designers who defined a situation, made up of conditions (matters of fact such as learner, content, context, and constraints) and values (matters of opinion such as goals, priorities, methods, and power). They selected methods (in terms of their scope, generality, precision, power, and consistency) to best serve the situation, seemingly embracing Cunningham's (1986) call 30 years later to think of instructional methods - before the situation is known - as "only guys" rather than opinion-based judgments of "good guys" and "bad guys," (p. 7) thereby avoiding a philosophical bias when selecting methods. Furthermore, Kanner et al.'s (1958) results eerily predicted Clark's (1994) words nearly 40 years later when he wrote that "media and their attributes have important influences on the cost or speed of learning but only the use of adequate instructional methods will influence learning" (p. 27).

To summarize, these researchers "found" the instructional theory framework as a foundation for designing instruction and making formative, iterative improvements over time. For the next 50 years, other researchers assembled the various blocks of knowledge that ultimately enabled Reigeluth and Carr-Chellman (2009a) to describe a robust representation of the instructional theory framework. Now in the 60th year since Kanner et al. (1958), Honebein and Honebein $(2013,2015)$ and Honebein $(2017,2019)$ have empirically tested various parts of the instructional theory framework, showing that the framework generally works as Reigeluth and Carr-Chellman (2009a) predicted — with, of course, a few twists and turns. 


\section{The Instructional Theory Framework}

We will now discuss the framework that helps one understand what an instructional theory is (and is not), along with the terminology that describes it. According to Reigeluth and Carr-Chellman (2009a), the instructional theory framework is a metatheory, in that it is a theory about theories. It is also a design theory, meaning that it focuses on creating things rather than describing things. Central to this idea of creating things is the concept of a method, which encapsulates the know-how a designer uses to create something.

Some methods reflect the process of design. For example, ADDIE (analysis, design, development, implementation, and evaluation) (Molenda, 2003) is a method for creating a learning experience. So is LLAMA (lot like agile management approach) (Czeropski \& Pembroke, 2017). Other methods reflect the process of learning. For example, a learning experience might include the method lecture, which promotes learning. Or it might include the method project-based learning. Thus, one can categorize methods in a variety of different ways for specific purposes, such as instructional approaches, instructional components, and content sequencing (Reigeluth \& Keller, 2009). The purpose we focus on in this paper is the latter of the two examples above, which we call an instructional method. Thus, for this paper, the instructional theory framework is best understood as a way to select instructional methods that promote learning. ${ }^{2}$

To select the most useful instructional methods, researchers rely on the instructional situation to guide them. As illustrated in Figure 1, the instructional situation has two parts, conditions and values (Reigeluth \& Carr-Chellman, 2009a; Reigeluth, Myers, \& Lee, 2017). Conditions are matters of fact about the situation that a designer can elicit empirically and objectively. They include information about the learner, content, and context for an instructional situation, and instructional design (ID) process constraints. Values are matters of opinion that are subjective in nature, yet a designer can elicit them empirically and multidimensionally from a variety of stakeholders, including, but not limited to, the designer, other designers, learners, instructors, clients, managers, subject-matter experts, and researchers. Stakeholders may express values in any type of media.

\footnotetext{
${ }^{2}$ This scope is aligned with what Reigeluth \& Carr-Chellman (2009a) call instructional-planning design theory.
}

The instructional theory framework appears lost. Isn't it time we find it again? Peter C. Honebein \& Charles M. Reigeluth. 


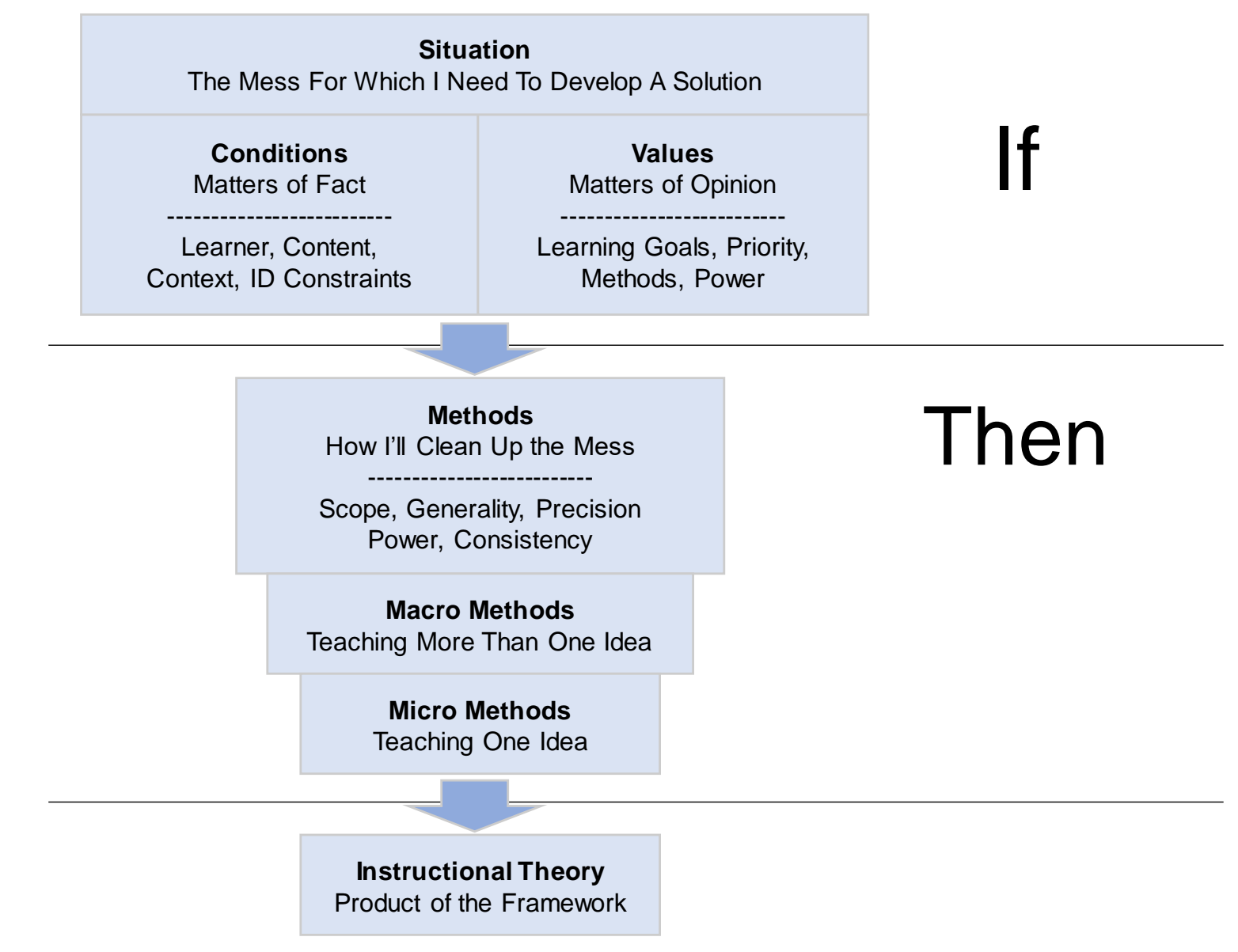

Figure 1: A simple representation of the instructional theory framework in action. We call the product (outcome) of this framework an instructional theory.

The instructional theory framework specifies four unique types of values: (1) Values about learning goals, which reflect stakeholders who hold different opinions about what should be learned; (2) Values about priority, which reflect whether a learning experience should favor effectiveness (mastering the behavior), efficiency (the lowest time or cost), or appeal (whether people like the learning experience or not); (3) Values about methods, which reflect what instructional methods stakeholders see as being most useful ("good guys," "bad guys," and "only guys"); and (4) Values about power, which reflect which stakeholders have the most power to get their way regarding the design of the learning experience.

Like conditions and values, instructional methods have their own unique characteristics, such as scope (micro, meso, macro), generality, precision, power, and consistency (Reigeluth \& Carr-Chellman, 2009a). Learning-experience designers use these method characteristics along with the conditions and values (situation characteristics) to select the best methods. In other words, the instructional theory framework is like a conditional heuristic (Figure 1) whereby a manager or client gives a learning-experience designer a situation (a mess), and the designer must then balance the conditions and values to select methods that enable the designer to create a 
solution that cleans up the mess.

The framework shown in Figure 1, is a pattern that produces and characterizes all instructional theories. Essentially, an instructional theory is the product of the instructional theory framework. It contains a collection of instructional methods that best fit the situation. If the knowledge a researcher generates lacks situational factors, it is an instructional model, not an instructional theory. And if it lacks instructional methods, it is likely a learning theory, not an instructional theory. Examples of instructional theories include those summarized in the four volumes of the "Green Books" (Instructional-Design Theories and Models) (Reigeluth, 1983; Reigeluth 1999; Reigeluth \& Carr-Chellman, 2009a; and Reigeluth, Beatty \& Myers, 2017), such as Shank, Berman, and Macpherson's (1999) goal-based scenarios, and Huitt, Monetti, and Hummel's (2009) direct approach to instruction.

Instructional theories do not need to be published in a book to be instructional theories. Because instructional theory is situational, anyone can create instructional theories for situations that are narrow or wide in scope, and they can improve, change, or "mash up" existing instructional theories in any way they want ... to fit the situation. Because instructional theories are situational, comparative research about which instructional theories are "best" is not useful and must be avoided. Instead, research must focus on the creation and improvement of instructional theories tailored to different situations.

\section{The Instructional Theory Framework Is Lost}

In this $60^{\text {th }}$ year since Kanner et al. (1958), the instructional theory framework that guides research investigating the efficacy of new and innovative instructional methods appears to be lost. There are three specific reasons for its disappearance, based upon our observations as journal reviewers, our subsequent review of previously published journal articles, and our analysis of the literature.

First, researchers do not appear to be using the instructional theory framework. Researchers' opinions about instructional methods seem to have once again devolved into "good guys" and "bad guys" rather than "only guys" (Cunningham, 1986) whose usefulness is dependent upon the situation. Researchers avoid overtly specifying the robust set of conditions present in an instructional situation: learner, content, context, and ID constraints. Their values about priorities are skewed toward effectiveness, forcing efficiency and appeal to the sidelines. And, once again, as if our field hasn't learned the lessons of the 1990s, instructional media is experiencing a resurgence as a false causal factor of instructional effectiveness (learning).

Second, the process researchers use to create instruction for their research treatments and measures lack good treatment design fundamentals. Central to this is formative evaluation (pilot testing) of instruction prior to conducting data collection with large groups of research participants. Formative evaluation is rarely reported in the method section yet it is so important to demonstrating the credibility of the treatments being tested. Also missing from the method section is the specification of well-formed instructional objectives or learner stories (Mager, 1984; Czeropski \& Pembroke, 2017) for what the treatments (methods) should accomplish. Finally, method sections are typically missing a full description of the assessments that demonstrates their alignment with the instructional objectives.

Third, the research methods that researchers use to investigate instructional treatments favor comparison, setting up a "good guys" versus "bad guys" competition. These kinds of research methods overlook a key aspect of the instructional theory framework - that all instructional methods are situational - that their effects vary from one situation to another.

The instructional theory framework appears lost. Isn’t it time we find it again? Peter C. Honebein \& Charles M. Reigeluth. 
Research to prove (to compare one package of methods with another) is not useful because it cannot be generalized to other situations. Research to improve is useful because it adds to current knowledge about configurations of methods, taking situational factors into account. As such, design research methods (Collins, Joseph, \& Bielaczyc, 2004) are far more useful for advancing knowledge about how to better help people learn in diverse situations, patterned on the instructional theory framework.

These reasons for the disappearance of the instructional theory framework are, at this point, trends we are seeing in the instructional design literature. Historically, the instructional theory framework was widely recognized and embraced by the instructional design field. Gentry (2016) reported that earlier volumes of Instructional-Design Theories and Models (Reigeluth, 1983; Reigeluth, 1999) were the most cited books (143 times and 128 times, respectively) in Educational Technology Research and Development (ETR\&D) through 2012 for the keywords cognitive, cognition, cognitivism, theory, and theories.

As time passed, the instructional theory framework's influence on the field seems to have waned in ETR\&D. Researchers can see this in the number of ETR\&D citations beyond 2012, which we searched using the ETR\&D website. Reigeluth (1983) citations gained 14, Reigeluth (1999) citations were no greater than what Gentry reported, and Reigeluth and Carr-Chellman (2009a) citations totaled 15 as of March 2020, with five of the citations attributable to the two authors of this paper. Only two papers in this time period report studies that investigate the usefulness of instructional methods within learning experiences. This number seems low to us.

The West et al. (2016) analysis suggests an explanation for why the instructional theory framework is lost: "In addition, for a field with a rich history in psychology/learning theory (Driscoll, 2004) and instructional theory (Reigeluth \& Carr-Chellman 2009), we were surprised that so few courses are required in this area" (p. 883). ${ }^{3}$

Clearly, instructional theory has a dissemination/adoption problem. One consequence of this is relatively useless comparative research, which we discussed a few paragraphs above. To find such research, we searched the word "traditional" in ETR\&D articles. In the literature, this word typically refers to a solution lacking desirable media and/or method element(s). This word appears in 1,282 papers. After reviewing a few papers, we revised the search to find the more commonly used terminology, such as "traditional instruction" (87 papers), "traditional method" (114 papers), and "traditional approach" (81 papers). We then generated a sample of papers between 2017 and 2019 that included the word "traditional."

We reviewed the method section in each paper to confirm the word "traditional" reflected an instructional treatment that researchers were comparing to a competing instructional treatment. The articles that met this criterion were Mavridis, Katmada, and Tsiatsos (2017); Zhou and Yadav (2017); Liu, McKelroy, Corliss, and Carrigan (2017); Fuad, Deb, Etim, and Gloster (2018); Gresalf, Riddle-Johnson, Loehr, and Nicols (2018); G-D Chen, Fan, C-Y Chang, Y-H Chang, and Y-H Chen (2018); Shadiev, Hwang, and Liu (2018), and Rominus, Eklund, Pesu, and Lyytinen (2019). None of these research articles include references linking their designs and conclusions with an instructional theory framework (Situation, Conditions, Values, and Methods) such as the one described above or any type of design theory (Reigeluth \& Carr-

\footnotetext{
${ }^{3}$ Note here that West et al. uses the generic terminology "instructional theory" as shorthand for the "instructional theory framework" we describe above. In conversations, we the authors use that similar shorthand, as do many other people. In this paper, "instructional theory framework" represents the Situation-Method algorithm, and "instructional theory" represents the product produced by that algorithm.
}

The instructional theory framework appears lost. Isn’t it time we find it again? Peter C. Honebein \& Charles M. Reigeluth. 
Chellman, 2009a) that “...identifies good methods for accomplishing goals (p. 7) ${ }^{4}$.

Shadiev, Hwang, and Liu (2018), is a representative example of how the instructional theory framework and its core design principles have gotten lost. The purpose of this research was to determine the efficacy of a mobile multimedia learning system (MMLS). To do this, Shadiev et al. compared their MMLS with what they called a "traditional method" or "traditional approach." The traditional method involved "the use of the printed textbook to study learning material," plus materials such as a "digital camera to take photos of objects from the real world, notebook, pen, pencil and voice recorder to describe objects in [writing] and verbally, and electronic dictionary to translate unfamiliar vocabulary" (pp. 903-904). We deconstructed this description to specify a medium (printed textbook) and a set of resources that enable the documentation of some phenomenon that students use for autonomous language learning. The primary instructional approach for both treatments appears to be authentic learning environments (Reigeluth \& Keller, 2009), with additional instructional components as described by Shadiev et al. (2019): “...our learning activity replicated real-world communicative tasks, and it incorporated discussion and practice with strategies for facilitating task performance. Furthermore, our learning activity promoted reflection on learning" (p. 898). Both treatment groups received the same content from the same instructor, participating in an hour-long classroom session three times a week to learn vocabulary and complete exercises from textbooks. The only real difference between the two groups appears to be the media (MMLS or textbook) and tools (MMLS or camera, pens, pencils, etc.) provided.

Ignoring the confounding variables in this study (Clark, 1985), the results, of course, showed that the MMLS treatment was more effective than the traditional method, yet no standard for mastery of an instructional objective, such as Kanner et al's. (1958) "washout" criterion, was specified. As for appeal, the researchers provided data only for the MMLS, but not for the traditional approach. And for efficiency, the researchers provided no data in terms of the cost, the amount of time to achieve mastery, and the overall workload of an instructor/facilitator to conduct the learning experiences.

While Shadiev et al. (2018) does, in some ways, embrace the spirit of the instructional theory framework as a means to improve instructional theories, it mostly illustrates the drift away from the instructional theory framework in the following three ways.

\section{No clear specification of content to be learned.}

There is the absence of clear learning goals guiding both treatments. While the research indicates the presence of a pretest and posttest (assessments), there is no specification of the conditions for performance, the learner's desired behavior, and a standard of performance that indicates mastery. This is inconsistent with the spirit of the instructional theory framework's conditions construct, which aims to synthesize facts about the learner, content, context, and constraints into an artifact — such as an instructional objective (Mager, 1984) — that guides the design of the learning experience.

On the other hand, the designers used the same assessment for both treatments. They also employed an existing learning experience as the comparator to their MMLS, which reflects the instructional theory framework's spirit of research that drives improvement.

\footnotetext{
${ }^{4}$ While this initial analysis was limited by time, it may suggest symptoms of a larger problem. Analysis of more articles beyond the 2017-2019 timeframe and inclusion of articles from other complimentary journals is necessary for a more complete picture of the situation, yet was beyond the scope of this paper.
}

The instructional theory framework appears lost. Isn't it time we find it again? Peter C. Honebein \& Charles M. Reigeluth. 


\section{Insufficient data across effectiveness, efficiency, and appeal measures to identify what was sacrificed.}

The researchers were diligent in collecting effectiveness measures, in terms of pretest and posttest scores. However, neither treatment provided data about its relative efficiency. The only information the article provided about efficiency (or lack thereof) is that the MMLS treatment participants had one week to get acquainted with the MMLS system, which suggests that the MMLS approach requires more instructor and learner time than the traditional approach. The researchers collected appeal data for the MMLS treatment, but not for the traditional approach.

\section{A focus on media (in terms of the autonomous learning resources) as the causal factor for the difference between the two treatments.}

Our reading of the research method leads us to conclude that the independent variable the researchers tested in this study is different media: the MMLS for one group, and books, pens, and paper for the other group. The research is not assessing an instructional method because the instructional approach (authentic learning environment) and instructional components (discussion, practice, and reflection) appear to be the same for both treatments.

\section{Researchers Must Rediscover the Instructional Theory Framework and Apply It Overtly through Six Research Principles}

Our field stands to lose much of its strength if we do not rediscover the instructional theory framework and learn to apply the framework overtly to the design and evaluation of learning experiences. The authors want to see the quality of learning-experience research improve, but worry that it may be supplanted once again by non-specific media research. Applying the instructional theory framework is not hard. Some designers may do it tacitly (Honebein \& Honebein, 2014) and, in some regards, the instructional theory framework is similar to a checklist of good practices. However, from a research perspective, very important details embedded in the instructional theory framework, such as effectiveness, efficiency, and appeal, go missing, as shown in the research samples described above. Our field will know it is on a better track when it sees research paper discussion sections talk about how an instructional theory framework was applied (or not), such as in Yuan and Kim (2017):

The success of an instructional method can be judged by its effectiveness, efficiency, and appeal (Reigeluth \& Carr-Chellman, 2009). Effectiveness relates to student achievement. Efficiency is measured mainly by the time and expenses of the instruction. Appeal is the extent to which the instruction captures students' continued attention (Reigeluth, 1983). Most instruction has to sacrifice one of the three learning outcomes to optimize the other two (Honebein \& Honebein, 2015). The findings of this study suggest that the peer assessment designs for both the ASPA and non-ASPA groups show similar levels of effectiveness and appeal. However, the design for the non-ASPA group was more efficient, evidenced by the lesser amount of time the nonASPA group spent in giving feedback on each evaluation criterion. (p. 44)

Based upon the authors' experience as researchers, peer-reviewers, and digital-learningexperience designers, we have synthesized six principles that are core to our science and help

The instructional theory framework appears lost. Isn't it time we find it again? Peter C. Honebein \& Charles M. Reigeluth. 
researchers embrace the ideals of the instructional theory framework:

1. Know complex systems qualitatively

2. Value the treatment design fundamentals

3. Practice unbiased consideration of instructional methods

4. Respect the instructional design iron triangle

5. Differentiate between methods and media

6. Know your personal instructional design theory

These principles also facilitate the transition between situation and methods that leads to superior instructional solutions, as well as to research that demonstrates an instructional solution's value. As we analyzed our thesis that the instructional theory framework is lost, we found that the reason is likely due to: (1) the training that researchers and practitioners receive in instructional design programs that marginalize these principles, and (2) the subsequent acceptance of peer-reviewed research that violates these principles. Therefore, the authors suggest researchers and practitioners find renewed inspiration to embrace the instructional theory framework through the following six principles.

\subsection{Complex Systems Must Be Known Qualitatively}

Learning-experience designers conduct the work they do in a living, self-organizing, complex system (You, 1993; Rowland, 1993, 2007; Solomon, 2000, 2002; Honebein, 2009). What this means is that learning experiences will behave in ways that researchers cannot predict or expect; their nature is emergent "... in that [it is] shaped and developed over time through an evolutionary process" (Honebein, 2009, p. 29). For example, an instructor can design and teach a class one semester, and then the very next semester can teach the same class again, and the experience for the instructor, the learners, and any other stakeholders will likely be different.

Reigeluth and Carr-Chellman's (2009b) and Honebein's (2019) explorations of the "galaxy" question, which is about whether some instructional methods have universal properties, provide evidence to support the proposition that the instructional theory framework represents a complex system. Merrill $(2002,2009)$ argued that some instructional methods are universal, that they are present in all good instruction, such as his first principles. However, those principles are described on a very imprecise level. The implementation of any of those principles will vary from one situation to another, making any reasonably precise description of the principle situational, in recognition of the complexity of instructional situations. Furthermore, given that the instructional theory framework provides categories for conditions (learner, content, context, and constraints), values (goals, priorities, methods, and power), and methods (scope, generality, precision, power, and consistency), the permutations of instances for each category a learningexperience designer could combine is immeasurable. In other words, situation and methods represent a complex system.

This idea of complexity is expanded upon by Cilliers (2000), who distinguished a system as simple, complicated, and complex based upon the distance from which one views that system. For example, an aquarium seen in one's home, viewed as a decoration, is a simple system. That same aquarium can seem be a complicated system when viewed by a person who needs to repair it, in terms of heaters, pumps, tubes, and chemicals. The aquarium becomes a complex system when a person sees the aquarium as an ecosystem, with an immeasurable number of variables.

When viewing a system at the simple and complicated levels, one can describe all the characteristics of the system. For example, one can specify all the parts of the aquarium's

The instructional theory framework appears lost. Isn't it time we find it again? Peter C. Honebein \& Charles M. Reigeluth. 
physical plant (heaters, pumps, tubes, etc.). However, when one views a system at a complex level, one cannot describe all its parts and the interactions among those parts. Thus, one uses qualitative characteristics to describe the system's nature (Cilliers, 2000):

1. A large number of elements

2. Interaction between the elements

3. Interactions are rich

4. Interactions are non-linear

5. Interactions have a short range

6. Interactions have loops

7. The system is open

8. Disequilibrium rules the system

9. The system has history

10. Each element is ignorant of the behavior of the system as a whole

Research methods to prove the usefulness of an instructional theory make little sense when the instructional situation surrounding the instructional treatment is a complex system. Comparative research will have limited generalizability and external validity because of the innumerable interactions among conditions, values, and methods. What makes more sense are instructional research methods that aim to improve the instructional theory; it is more important to learn how to do things better than to compare.

The goal to improve rather than prove is consistent with You's (1993) and Collins, Joseph, and Bielaczyc's (2004) concept of design research. This research approach arose from "...the complexities of real-world situations and their resistance to experimental control" (p. 18). The design research approach is useful because it "...entails qualitative and quantitative observations, just as Consumer Reports evaluates products" (p. 19). Thus, using mixed methods for instructional theory research is reasonable, as it aligns with Cilliers (2000) in that the views of simple systems, complicated systems, and complex systems represent a continuum of shades bounded by quantitative on the left (simple system) and qualitative on the right (complex system) (Figure 2). In research categories such as exploratory, developmental, formative, and design, qualitative/mixed approaches are more useful, whereas for confirmatory or experimental research, quantitative/mixed approaches are more useful.

Simple Systems

More Quantitative
Complicated Systems
Complex Systems

\section{More Qualitiative}

\begin{abstract}
Figure 2: The simple system, complicated system, and complex system continuum. Quantitative research methods may be more useful toward the left, while qualitative research methods may be more useful to the right.
\end{abstract}

\title{
5.2 Value the Treatment Design Fundamentals
}

A design fundamental is a "good practice" that one expects a learning-experience designer to overtly apply in the design of a learning experience. Designers can also know a design fundamental as a flexible design judgment or an inflexible core judgment (Nelson \& 
Stolterman, 2012; Boling et al., 2017), both of which take on a role as "guarantors of success" (p. 207). For us, treatment design fundamentals focus on three key instructional design practices: (1) clearly specified situations (conditions and values) that are typically stated in the form of instructional objectives, (2) aligned assessments, and (3) formative evaluation that demonstrates a learning experience can achieve the mastery standard specified in the objective.

\subsubsection{Instructional Objectives}

When a learning-experience designer conducts an instructional analysis, the designer gathers data about the situation in the form of conditions and values. The designer then synthesizes all these situational factors into a form that enables the selection of instructional methods... an instructional objective.

You (1993) suggested that instructional objectives may not have a place in learning experiences that function as complex systems, arguing "...that providing specific objectives delimits active learning" (p. 28). Wilson and Cole (1991) (as cited in You, 1993), supported this by saying " $\ldots$ incomplete learning specifications can nonetheless lead toward complete learning outcomes" (p. 28). We agree with these authors that complex learning experiences can afford both active learning and complete learning outcomes, but we disagree with their suggestion that instructional objectives impede these types of outcomes. These authors appear to have a rather limited view of instructional objectives, evidenced by You's (1993) statement that "Objectivedriven ISD models, however, are applicable in certain areas, such as in training of technical or simple tasks" (p. 28).

Our view is very different, as we believe (and have achieved it in practice) that one can specify an instructional objective (or learner story) for any range of tasks. Cillers (2000) himself saw complex systems as tasks being worthy of measurable outcomes when he used such phrases as "living organism or a growing economy" (p. 12) to describe classic complex systems in a measurable way. Collins et al. (2004) wrote, "Goals, critical elements, and their interactions need to be described in enough detail, so that it is possible to evaluate how well the design was implemented in different settings" (p. 38). This connects us back to the instructional theory framework's constructs of conditions and values.

A well-formed instructional objective has three parts: the conditions for performing the behavior, the behavior, and a standard of performance (criteria for mastery). There are specific rules for each part that maintain logical consistency and hierarchy of the instructional objective (Mager, 1984). In instructional theory framework terms, the specification of mastery is called values about goals (Reigeluth \& Carr-Chellman, 2009a), and since it is a value (a matter of opinion), a designer can define it quantitatively, qualitatively, or some mixture of both.

Recent acceptable alternatives to the Mager-style instructional objectives are demonstration objectives (Reigeluth \& An, in press) and learner stories (Czeropski \& Pembroke, 2017), the latter of which are associated with adaptive/agile design methodologies. These methodologies provide a similar and perhaps a more empathic approach, through the use of empathy maps, to specifying the learning we expect a learning experience to deliver.

\subsubsection{Aligned Assessments}

Researchers must specifically link and align instructional objectives with assessments. Assessments not only confirm mastery of desired behaviors, but also provide data about formative improvements. Furthermore, if a researcher is assessing improvements associated with two or more instructional solutions, as Kanner et al. (1958) did, researchers must base the

The instructional theory framework appears lost. Isn’t it time we find it again? Peter C. Honebein \& Charles M. Reigeluth. 
solutions upon the same instructional objective(s) and correspondingly, the same assessment.

The majority of research we reviewed above uses the same assessments when comparing two or more instructional methods, which is good. Yet, what is typically missing in criterionreferenced assessments is an indication of acceptable mastery. For example, Treatment A might report test performance of $83 \%$, while Treatment B might report test performance of $89 \%$. If the instructional objective guiding both treatments lacks mastery criteria, it becomes very difficult to assess the efficacy of each treatment across the outcomes of effectiveness, efficiency, and appeal. What if an assessment score of $80 \%$ in the above example signified mastery? Does Treatment B's $6 \%$ advantage in effectiveness outweigh possible disadvantages in efficiency and appeal? Researchers must identify acceptable mastery, just as Kanner et al. (1958) did with their washout criteria so that other researchers can assess the improved learning effects within the context of efficiency and appeal.

\subsubsection{Formative Evaluation}

Learning experience research must be more about improving and less about proving. Formative evaluation is the foundation of Collins et al. (2004) design research approach. Its purpose is to improve learning experiences, as measured by effectiveness, efficiency, and appeal. Research to improve learning experiences typically begins with development, when researchers try out pieces of instruction using pilot-testing techniques such as single-subject testing (Brenneman, 1986) or expert reviews. Researchers need to communicate the results of these pilot tests to readers in the method section of their reports to demonstrate that the learning experience treatments are of high quality.

When researchers implement a learning experience treatment (delivery to actual learners), they collect formative data about its effectiveness, efficiency, and appeal. From that point, the learning experience may undergo any number of formative improvements over various iterations in its design research lifecycle. Why? Because the learning experience will never be perfect; the situation (a complex system) is always changing, forcing the learning experience to change and adapt to deliver the right proportions of effectiveness, efficiency, and appeal. Thus, researchers must not only report the changes in methods and the resulting changes to effectiveness, efficiency, and appeal, but also the changes to the situation.

Given the situational nature of instructional theory, researchers must embrace design research methodologies that are iterative and seek to improve instructional theories for a given situation (see, for example, Barab \& Squire, 2004; Collins et al., 2004; Design-Based Research Collective, 2003; Reigeluth \& Frick, 1999; Wang \& Hannafin, 2005). Researchers must abandon comparative research that attempts to "prove" one learning experience is better than another because such research is not useful; it does not respect the situational nature of instructional theory.

To summarize, treatment design fundamentals are specific instructional design practices that researchers must report in the methods section of their papers. Researchers must: (1) describe the situation, typically as well-formed instructional objectives that reflect the situation; (2) create assessments that directly align with the instructional objectives; (3) conduct and report formative evaluation during development that demonstrates their learning experience can achieve the mastery requirement specified in the instructional objective; (4) put their learning experience into production to establish baseline performance across effectiveness, efficiency, and appeal, and (5) iterate and improve their learning experience to find the best balance of effectiveness, efficiency, and appeal over time.

The instructional theory framework appears lost. Isn’t it time we find it again? Peter C. Honebein \& Charles M. Reigeluth. 


\subsection{Practice Unbiased Consideration of Instructional Methods}

Researchers must adopt a mindset that considers all instructional methods as having unknown or neutral usefulness until the instructional situation is known, at which time they will have data to assess an instructional method's usefulness (Honebein, 2016, 2019). This helps avoid philosophical bias. Honebein's research showed that designers have a pre-existing bias toward certain instructional methods; in the instructional theory framework this is called values about methods (Reigeluth \& Carr-Chellman, 2009a). For example, as shown in Figure 3, many designers view authentic tasks as very useful, whereas those same designers view peer-based or cooperative methods as less useful. This type of biased thinking can lead designers to reject instructional methods that would be very useful in the situation, just because those methods are incompatible with their biases.

The less useful vs. very useful scenario, originally described by Cunningham (1986), is commonly seen in studies when a researcher calls out the straw man, traditional instruction (the less-useful design), and desires to compare its effectiveness to whatever the new thing is (the very-useful design). The typical problems with this sort of research are that: (1) the designer does not articulate the treatment design fundamentals (situational factors, aligned assessments, and formative evaluation) that inform the design of both methods, and (2) the designer neglects to collect data about the effects of both methods regarding effectiveness, efficiency, and appeal.

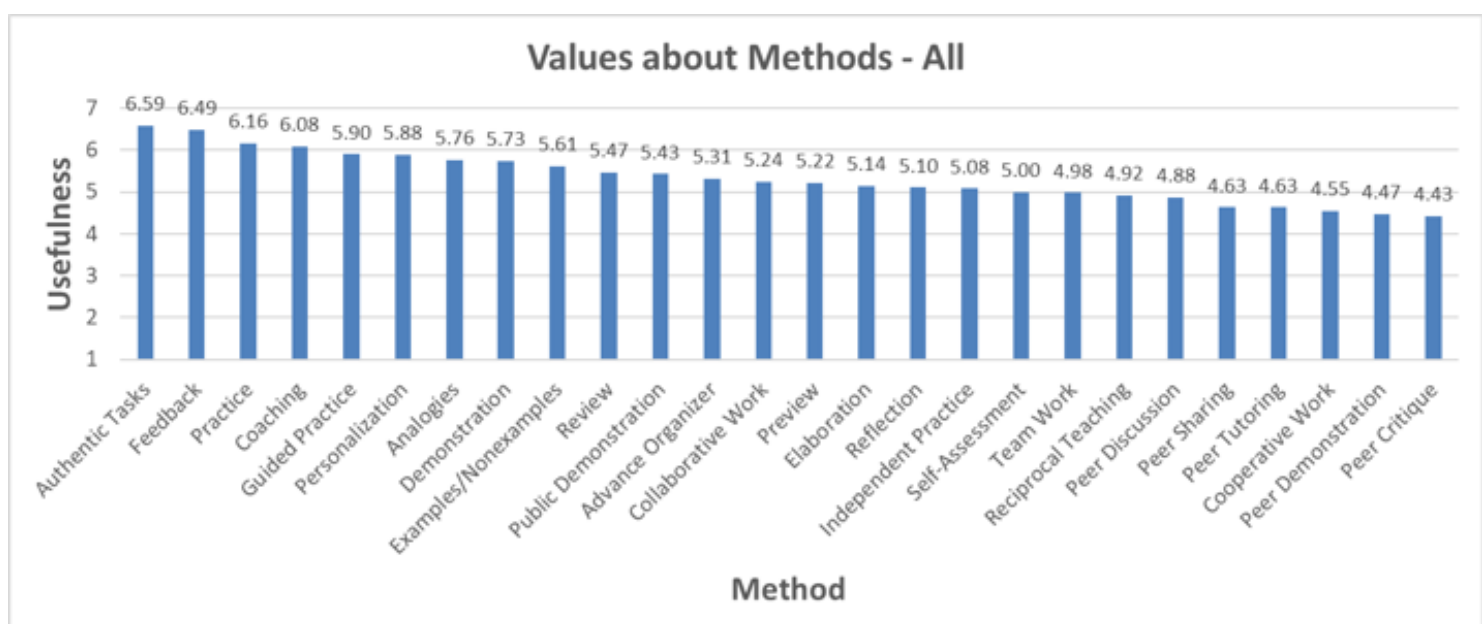

Figure 3: Values about methods, combining data from Introductory and Capstone groups. Methods to the left were perceived by designers as more useful (powerful) than methods to the right. From Honebein (2019).

\subsection{Respect the Instructional Design Iron Triangle}

All instructional designs involve some sort of sacrifice (Gropper \& Kress, 1965; Tosti \& Ball, 1969; Clark \& Angert, 1980; Hannafin \& Rieber, 1989). Honebein and Honebein's (2015) research into this topic suggested that an instructional design iron triangle likely exists in all instructional design projects (see Figure 4). The theory of the iron triangle is that if you have three competing factors, you can only maximize two of them; you always sacrifice one. To illustrate this principle, in project management, time, cost, and scope are the competing factors. If you want a project completed faster (time), then either it will cost you more (cost) or you must remove certain features (scope). In instructional design, the competing factors (outcomes) are effectiveness, efficiency, and appeal. For example, if a designer favors effectiveness and appeal, 
the designer will sacrifice efficiency. Favoring efficiency and appeal sacrifices effectiveness, and favoring effectiveness and efficiency sacrifices appeal. Researchers must design their research studies (design experiments) to include all three types of data, and then discuss which outcomes were benefitted and which were sacrificed, especially when assessing two or more instructional designs.

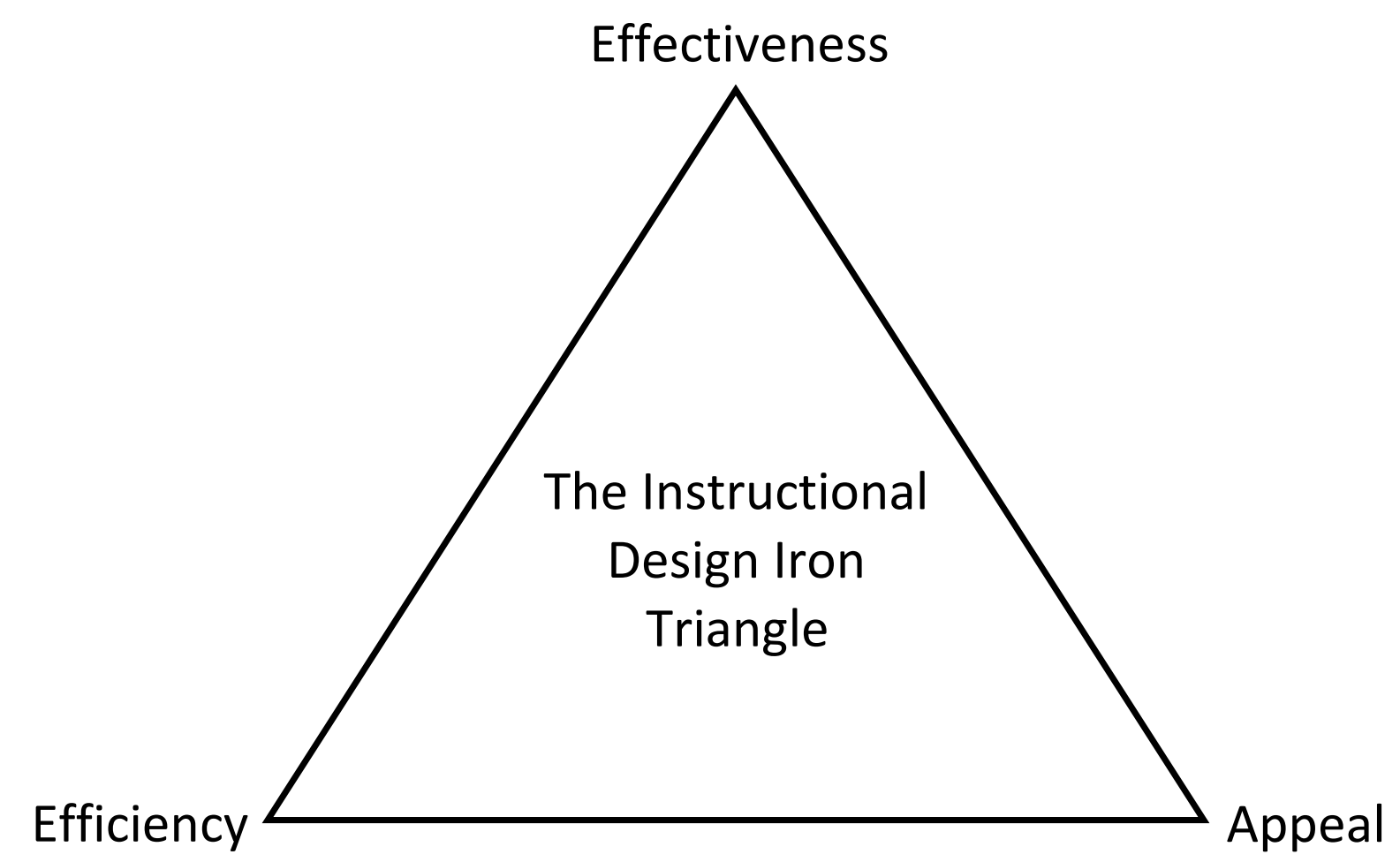

Figure 4: The Instructional Design Iron Triangle depicts the balance of effectiveness, efficiency, and appeal. From Honebein and Honebein (2015)

\subsection{Differentiate between Methods and Media}

Methods and media have a unique influence on effectiveness, efficiency, and appeal. We have already defined instructional methods earlier in this paper. Examples of instructional methods include lecture, drill and practice, and apprenticeship. Media is, of course, the communication channel that carries instructional methods to learners (Heinich, Molenda, \& Russell, 1989). Media itself is a method, and as such one should differentiate between instructional methods and media methods. Media methods include such things as words, diagrams, pictures, films, models, and realia, organized across categories of abstract, iconic, and enactive (Bruner, 1966).

We feel that the Clark/Kozma media debates of the 1990s were settled in favor of Clark (1985, 1986, 1994), whose position was that media methods influence efficiency, whereas instructional methods influence efficiency and effectiveness (as appeal was not addressed in the debates). Our observations and conversations within the instructional design field suggest that comparative research studies tend to mistake media methods for instructional methods as the independent variable. For example, at the 2019 American Educational Communications and Technology (AECT) conference, a session presenter classified "video program" as an 
instructional method.

This is not unexpected, since we feel that researchers like us were all immunized in the 1990s and the media methods disease diminished - so we, as a field, stopped talking about the relationship between effectiveness, efficiency, and appeal and media methods. Now, we feel that there are researchers, editors, and reviewers who never got their immunization. In other words, there are researchers still seeking to conduct this kind of effectiveness-focused, media-driven comparative research without overtly framing it in the context of the Clark/Kozma debates, as Clark, Tanner-Smith, and Killingsworth (2016) appropriately do in their meta-analysis of digital games:

Thus, harkening back to the Clark/Kozma debates of the 1980s and 1990s about the relative importance of studying medium versus design (e.g., Clark, 1994; Kozma, 1994), games as a medium definitely provide new and powerful affordances, but it is the design within the medium to leverage those affordances that will determine the efficacy of a learning environment ( $\mathrm{p}$. 116).

Acknowledgements such as this signal that the researcher is aware of the issue and its potential limitations. Hopefully the viewpoint we have presented above will re-open the conversation so that the new researchers our field is training get their immunization.

While we keep an open mind that some enterprising researcher might someday disprove that media (all else being equal) has no effect on effectiveness, the elephant that remains in the room is what influences appeal? This was not addressed in the debate cited above. However, studies suggest that both methods and media influence appeal. English and Reigeluth (1996) and Honebein $(2016,2019)$ have shown that learners have different feelings toward various instructional methods; some they like better than others. For visual media, Vandermeer (1954) showed that learners find color films more intrinsically appealing than black/white instructional films. McKenna (1993) found similar results for audio media, specifically audio recordings for children, where "talk" was less appealing than "popular music."

While the instructional theory framework, as described by Reigeluth and Carr-Chellman (2009a), doesn't have a separate box for media methods (they fall within the general methods construct), Gibbons and Rogers' (2009) extension of the instructional theory framework suggests a concept called layering. Layering aims to represent various "specialized design subproblems" (p. 315) that guide the creation of learning experiences. The seven layers are:

1. Content

2. Strategy

3. Message

4. Control

5. Representation

6. Media-Logic

7. Data Management

Instructional methods are associated with the strategy, message, and control layers. Media methods are associated with the representation and media-logic layers. All these layers still function within the instructional theory framework, in that the situation guides a designer in choosing the most useful methods that are available in each layer. Yet, researchers must exercise caution when assessing the impact of the media layers, limiting them to just efficiency and

The instructional theory framework appears lost. Isn't it time we find it again? Peter C. Honebein \& Charles M. Reigeluth. 
appeal.

\subsection{Know Your Personal Instructional Design Theory}

For more than 15 years now, the authors have taught a capstone instructional theory framework course for graduate students. The course culminates in students writing their own personal theory of instruction. In writing their personal theory paper, students consider the conditions (learner, content, context, constraints) and values (about goals, outcomes, methods, power) associated with their situation, and discuss the instructional methods that reflect their "stamp" as a designer.

The activity our students complete should be an activity that all designers regularly engage in as well, since the activity is all about drawing a line in the sand about your design principles (Brown \& Campione, 1996; Stolterman \& Nelson, 2000; Collins et al., 2004; Boling et al., 2017). We see such design principles connected to important emerging ideas from the above authors related to design character, design judgment, core judgment, and guarantor of design. As we understand these terms, one's design character represents inherent, assumed responsibilities for both creative process and outcomes. Design judgment involves creativity and innovation, integrating multiple forms of judgment associated with those aims. Stolterman and Nelson (2000) refer to design judgment as "an act of faith" (p. 8). Ultimately, after a designer experiences the results of their design judgments, design judgments contribute to core judgment, in which certain judgments over time become fixed and very hard to change. For example, the treatment design fundamentals we discuss in this paper are, for us, core judgments.

While it remains a fuzzy concept, guarantor of design is mostly about responsibility and accountability, which many of us have trouble accepting. We move responsibility, hide responsibility, and remove responsibility. But ultimately, whether or not one acts as the guarantor of design comes back to one's design character and one's belief "in his or her capacity to make good judgments" (p. 8). That belief is reinforced in terms of how one reflects on their actions.

We think one's design principles were meant to be dynamic, not static. As the comedian Groucho Marx once said, "Those are my principles, and if you don't like them ..., well, I have others." Groucho was wise, as he appears to have known the instructional theory framework's foundational idea that situation drives methods, or in this case, principles. Whether a learningexperience designer is eclectic or orthodox in their adoption of learning theories and instructional methods (Yancher \& Gabbitas, 2011; Honebein \& Sink, 2012), the designer's choice of methods must be dependent on the situation. Designers should not assume even Merrill's $(2002,2009)$ first principles to be appropriate in all situations (Honebein, 2019). It is through the ideas of formative evaluation, design research, and reflection-in-action/reflection-on-action that one's principles increase and decrease in strength.

\section{Conclusion}

The instructional theory framework is a cornerstone that must guide our field's research and practice, as it did tacitly in Kanner et al. (1958). The foundations of situation and methods are simple, logical, and aligned with good practice. Philosophically, the instructional theory framework addresses both the objective world (conditions) and the subjective world (values), which mimics what researchers experience in the real world. It provides researchers a means to assess and articulate their design judgment, enabling them to be more confident in their role of guarantors of design (Stolterman \& Nelson, 2000). And as shown by Honebein and Honebein 
(2014, 2015) and Honebein $(2017,2019)$, the instructional theory framework functions as expected. The instructional theory framework's key benefit is that it guides designers in creating learning experiences that have a higher relative advantage (effectiveness, efficiency, and appeal), better compatibility, lower complexity, easier observability, and actionable trialability, thus increasing the chance for adoption.

Yet, it is clear to us that the instructional theory framework has its own dissemination problem, which impacts the quality of research and practice. This paper is our first product aimed to correct this. Here are some specific recommendations for future products.

\subsection{Integrate the Instructional Theory Framework into Introductory Instructional Design Classes}

The instructional theory framework content is typically reserved for capstone classes in Ed.D. and Ph.D. programs. This limits the dissemination of the situation and methods framework. A better approach is to shift the key elements of the situation and methods framework into introductory instructional design classes. The story of how situations and methods interact within the messy context of power and subjective decisions helps new entrants to our field see the usefulness and practical application of our science. To attract greater interest, perhaps we will need to rebrand the instructional theory framework into something more compelling and approachable, such as the Learning Experience Framework. After all, according to the literature, instructional designers don't apply theory knowingly, only tacitly (Honebein \& Honebein, 2014). To jumpstart this idea, the authors suggest developing and disseminating an open educational resource (OER) for the Learning Experience Framework.

\subsection{Train Peer Reviewers to Apply the Principles of the Instructional Theory Framework When Evaluating Design Research}

As peer reviewers and vocal advocates of instructional theory, the authors obviously use the instructional theory framework lens as a criterion for evaluating peer-reviewed research. It enables us to achieve the aim of peer review, which is to guide researchers in improving their work. While the lens of the instruction theory framework has caused us to reject and redirect many research papers, our review comments that introduce authors to the instructional theory framework and the willingness (sometimes begrudgingly) of authors to embrace it have guided papers to publication that may not have otherwise achieved that goal.

With this in mind, as well as the feedback we read from other reviewers during the peer review process, it is clear that for research papers that involve the study of instructional methods at any level (simple, complicated, complex; micro, meso, macro), the instructional theory framework described in this paper (or other frameworks that align with design theory) should be part of any review. This is not to say that we as a field should reject research papers because they don't embrace all of the instructional theory framework's prescriptions. Rather, we should use the instructional theory framework as a way to guide researchers in explaining the limitations and implications of their research. For example, in the Yuan and Kim (2018) and Lange (2019) studies, the authors clearly described what they included or missed. In Yuan and Kim, they described the inclusion of all three effectiveness, efficiency, and appeal measures. In Lange, the author reported the absence of the appeal measure. To jumpstart this idea, the authors once again suggest developing an OER that describes how to use the instructional theory framework as a peer review criterion, sharing it with journal editors to find the best way to first ratify the criterion, and then disseminating it to both reviewers and authors.

The instructional theory framework appears lost. Isn’t it time we find it again? Peter C. Honebein \& Charles M. Reigeluth. 


\subsection{Train Researchers in Design Research}

It is unfortunate that research in our field continues to evaluate learning experiences in a comparative, "good guys" versus "bad guys" horse race. We all know why: the researcher archetype is solidly grounded in a "comparing things" paradigm where quantitative statistics is the indicator of quality. Comparative, experimental research has its place in our field when the primary purpose is to prove, such as in the Hancock-Niemic, Lin, Atkinson, Renkl, and Wittwer (2015) study that compared the efficacy of four types of math practice - specific, named, microlevel instructional methods. Because macro-level learning experiences reflect a situational, complex system, proofs are difficult to generalize. Therefore, such research has less value when researching macro-level learning experiences. However, when a researcher views phenomena as a complex system, then more qualitative approaches might be more useful.

Design research (Collins et al., 2004) provides a means to balance the qualitative and quantitative, enabling researchers to focus on iteration and improvement that considers varying priorities regarding effectiveness, efficiency, and appeal. Thus, similar to our call for overtly recognizing learning-experience design activities as being under an instructional theory framework umbrella, research on those instructional theories that the framework produces must be under a design-research umbrella. To get there, our field must train researchers in design research, and researchers must use it when it is compatible with the research situation and when conducting peer reviews.

Received: 26 de marzo de 2020

Accepted: 4 de julio de 2020

Published: 30 de septiembre de 2020

Honebein, P.C. \& Reigeluth, C.M. (2020). The instructional theory framework appears lost. Isn't it time we find it again? RED. Revista Educación a Distancia, 20(64). http://dx.doi.org/10.6018/red.405871

\section{Funding}

This research has not received any specific grant from funding agencies in the public, commercial or non-profit sectors.

\section{References}

Barab, S. A., \& Squire, K. D. (2004). Design-based research: Putting our stake in the ground. Journal of the Learning Sciences, 13(1), 1-14.

Boling, E., Alangari, H., Hajdu, I. M., Guo, M., Gyabak, K., Khlaif, Z., Kizilboga, R., Tomita, K., Alsaif, M., Lachheb, A., Bae, H., Ergulec, F., Zhu, M., Basdogan, M., Buggs, C., Sari, A., and Techawitthayachinda, R.I. (2017). Core judgments of instructional designers in practice. Performance Improvement Quarterly, 30(3), 199-219. DOI:

10.1002/piq. 21250

The instructional theory framework appears lost. Isn't it time we find it again? Peter C. Honebein \& 
Bostwick, J. A., Calvert, I. W., Francis, J., Hawkley, M., Henrie, C. R., Hyatt, F. R., Juncker, J., \& Gibbons, A. S. (2014). A process for the critical analysis of instructional theory. Educational Technology Research and Development, 62(2), 571-582. https://doiorg.proxyiub.uits.iu.edu/10.1007/s11423-014-9346-5

Brenneman, J. (1989, March). When you can't use a crowd: Single-subject testing. Performance \& Improvement, 28(3) 22-25.

Brown, A., \& Campione, J. (1996). Psychological theory and the design of innovative learning environments: On procedures, principles, and systems. In L. Schauble \& R. Glaser (Eds.), Innovations in learning: New environments for education (pp. 289-325). Mahwah, NJ: Lawrence Erlbaum Associates.

Bruner, J. S. (1966). Toward a theory of instruction. Cambridge, MA: Belknap Press.

Chen, G-D., Fan, C-Y., Chang, C-Y., Chang, Y-H., \& Chen, Y-H. (2018). Promoting autonomy and ownership in students studying English using digital comic performance-based learning. Educational Technology Research and Development, 66, 955-978. https://doi.org/10.1007/s11423-018-9597-7

Cillers, P. (2000). Complexity and postmodernism. London: Routledge.

Clark, D. B., Tanner-Smith, E. E., and Killingsworth, S. S. (2016). Digital games, design, and learning: A systematic review and meta-analysis. Review of Educational Research, 86(1), 79-122. https://www.jstor.org/stable/24752870

Clark, R. E. (1985). Evidence for confounding in computer-based instruction studies: Analyzing the meta-analyses. Educational Communications and Technology Journal, 33(4), 249262.

Clark, R. E. (1986). Absolutes and angst in educational technology research: A reply to Don Cunningham. Educational Communications and Technology Journal, 34(1), 8-10.

Clark, R. E. (1994). Media will never influence learning. Educational Technology Research and Development, 42(2), 21-29.

Clark, F. E., \& Angert, J.F. (1980). Instructional design research and teacher education. Paper presented at the Annual Meeting of the Southwest Educational Research Association (San Antonio, TX, February 8, 1980). ERIC Document 183528.

Collins, A., Joseph, D., \& Bielaczyc, K. (2004). Design research: Theoretical and methodological issues. The Journal of the Learning Sciences, 13(1), 15-42. https://doi.org/10.1207/s15327809j1s1301_2

Cunningham, D. J. (1986). Good guys and bad guys. Educational Communications and Technology Journal, 34(1), 3-7.

Czeropski, S., \& Pembroke, C. (2017). E-learning ain't performance: Revising HPT in an era of agile and lean. Performance Improvement, 56(8), 37-47. 10.1002/pfi.21728

Design-Based Research Collective. (2003). Design-based research: An emerging paradigm for educational inquiry. Educational Researcher, 32(1), 5-8.

English, R. E., \& Reigeluth, C. M. (1996). Formative research on sequencing instruction with the elaboration theory. Educational Technology Research and Development, 44(1), 23-42.

Fuad, M., Debzani, D., Etim, J., \& Gloster, C. (2018). Mobile response system: a novel approach to interactive and hands-on activity in the classroom. Educational Technology Research and Development, 66, 493-514. https://doi.org/10.1007/s11423-018-9570-5

Gentry, W. A. (2016). Citation context analysis of theory use in instructional design and technology academic articles (Doctoral Dissertation). Retrieved from https://vtechworks.lib.vt.edu/handle/10919/82931

The instructional theory framework appears lost. Isn't it time we find it again? Peter C. Honebein \& 
Gibbons, A. S., \& Rogers, P. C. (2009). The architecture of instructional theory. In C. M. Reigeluth \& A. Carr-Chellman (Eds.), Instructional-design theories and models: Building a common knowledge base (Vol. III) (pp. 305-326). Hillsdale, NJ: Lawrence Erlbaum Associates.

Gresalfi, M. S., Rittle-Johnson, B., Loehr, A., \& Nichols, I. (2018). Design matters: Explorations of content and design in fraction games. Educational Technology Research and Development, 66, 579-596. https://doi.org/10.1007/s11423-017-9557-7

Gropper, G. L. \& Kress, G.C. (1965). Individualizing instruction through pacing procedures. $A V$ Communications Review, 13(2), 165-182.

Hancock-Niemic, M. A., Lin, L., Atkinson, R. K., Renkl, A., \& Wittwer, J. (2016). Examplebased learning: exploring the use of matrices and problem variability. Educational Technology Research and Development, 64, 115-136.

Hannifin, M. J., \& Rieber, L.P. (1989). Psychological foundations of instructional design for emerging computer-based instructional technologies, part II. Educational Technology Research and Development, 37(2), 102-114.

Heinich, R., Molenda, M., \& Russell, J. D. (1989). Instructional Media ( $3^{\text {rd }}$ Ed.). Macmillian: New York.

Honebein, P. C. (2009, January-February). Transmergent learning and the creation of extraordinary learning experiences. Educational Technology, 49(1), 27-34.

Honebein, P. C. (2016). The influence of values and rich conditions on designers' judgments about useful instructional methods. Educational Technology Research and Development, 65(2), 341-357. https://doi.org/10.1007/s11423-016-9485-y

Honebein, P. C. (2019). Exploring the galaxy question: The influence of situation and first principles on designers' judgments about useful instructional methods. Educational Technology Research and Development, 67(3), 665-689. https://doi.org/10.1007/s11423019-09660-9

Honebein, P. C., \& Honebein, C. H. (2014). The influence of cognitive domain content levels and gender on designer judgments regarding useful instructional methods. Educational Technology Research and Development, 62(1), 53-69. https://doi.org/10.1007/s11423013-9322-5

Honebein, P. C., \& Honebein, C. H. (2015). Effectiveness, efficiency, and appeal: pick any two? The influence of learning domains and learning outcomes on designer judgments of useful instructional methods. Educational Technology Research and Development, 63(6), 937-955. https://doi.org/10.1007/s11423-015-9396-3

Honebein, P. C., \& Sink, D. L. (2012). The practice of eclectic instructional design. Performance Improvement, 51(10), 26-31.

Huang, W. D., \& Wu, C-G. (2017). An analysis of instructional design and technology departments. Educational Technology Research and Development, 65, 1495-1521. https://doi.org/10.1007/s11423-017-9529-y

Huitt, W. G., Monetti, D. D., \& Hummel, J. H. (1999). Direction approach to instruction. In C.M. Reigeluth (Ed.), Instructional-design theories and models: A new paradigm of instructional theory, volume II (pp. 73-97). Hillsdale, NJ: Lawrence Erlbaum Associates.

Kanner, J. H., Katz, S., Mindak, W., \& Goldsmith, P. (1958). Television in army training: Evaluation of television for "intensive" training and for reducing instructor and student training time and costs. Audio-Visual Communications Review, 6, 255-290. https://doiorg.proxyiub.uits.iu.edu/10.1007/BF02768458

The instructional theory framework appears lost. Isn't it time we find it again? Peter C. Honebein \& 
Lange, A. A. (2019). Technology, instructional methods, and the systemic messiness of innovation: improving reading fluency for low socio-economic elementary school students. Educational Technology Research and Development, 67, 1333-1350. https://doi.org/10.1007/s11423-019-09675-2

Lee, J., \& Jang, S. (2014). A methodological framework for instructional design model development: Critical dimensions and synthesized procedures. Educational Technology Research and Development, 62, 743-765. 10.1007/s11423-014-9352-7

Liu, M., McKelroy, E., Corliss, S. B., \& Carrigan, J. (2017). Investigating the effect of an adaptive learning intervention on students' learning. Educational Technology Research and Development, 65, 1605-1625. https://doi.org/10.1007/s11423-017-9542-1

Mager, R. F. (1984). Preparing instructional objectives. Belmont, CA: Lake.

Mavridis, A., Katmada, A., \& Tsiatsos, T. (2017). Impact of online flexible games on students' attitude towards mathematics. Educational Technology Research and Development, 65, 1451-1470. https://doi.org/10.1007/s11423-017-9522-5

McKenna, L. M. (1993). The relationship between attributes of a children's radio program and its appeal to listeners. Educational Technology Research and Development, 41(1), 17-28.

Merrill, M. D. (2002). First principles of instruction. Educational Technology Research and Development, 50(3), 43-59.

Merrill, M. D. (2009). First principles of instruction. In C. M. Reigeluth \& A. Carr-Chellman (Eds.), Instructional-design theories and models: Building a common knowledge base (Vol. III) (pp. 41-56). Hillsdale, NJ: Lawrence Erlbaum Associates.

Molenda, M. (2003). In search of the elusive ADDIE model. Performance Improvement, 42(4), 34-36.

Nelson, H. G., \& Stolterman, E. (2012). The design way: Intentional change in an unpredictable world (2nd ed.). Cambridge, MA: MIT Press.

Pelánek, R. (2019). Managing items and knowledge components: domain modeling in practice. Educational Technology Research and Development, 67. https://doi.org/10.1007/s11423019-09716-w

Reigeluth, C.M. (1983). Instructional Design: What is it and Why is it? In C.M. Reigeluth (Ed.), Instructional-design theories and models: An overview of their current status (pp. 3-36). Hillsdale, NJ: Lawrence Erlbaum Associates.

Reigeluth, C.M. (1999). What is instructional-design theory and how is it changing? In C.M. Reigeluth (Ed.), Instructional-design theories and models: A new paradigm of instructional theory, volume II (pp. 5-29). Hillsdale, NJ: Lawrence Erlbaum Associates.

Reigeluth, C. M., Beatty, B. J., \& Myers, R. D. (Eds.). (2017). Instructional-design theories and models, Volume IV: The learner-centered paradigm of education. New York, NY: Routledge.

Reigeluth, C.M. \& Carr-Chellman, A. (2009a). Understanding instructional theory. In C. M. Reigeluth \& A. Carr-Chellman (Eds.), Instructional-design theories and models: Building a common knowledge base (Vol. III) (pp. 3-26). Hillsdale, NJ: Lawrence Erlbaum Associates.

Reigeluth, C.M. \& Carr-Chellman, A. (2009b). Situational principles of instruction. In C. M. Reigeluth \& A. Carr-Chellman (Eds.), Instructional-design theories and models: Building a common knowledge base (Vol. III) (pp. 57-68). Hillsdale, NJ: Lawrence Erlbaum Associates.

Reigeluth, C. M., \& Frick, T. W. (1999). Formative research: A methodology for creating and

The instructional theory framework appears lost. Isn't it time we find it again? Peter C. Honebein \& 
improving design theories. In C.M. Reigeluth (Ed.), Instructional-design theories and models: A new paradigm of instructional theory, volume II (pp. 633-651). Hillsdale, NJ: Lawrence Erlbaum Associates.

Reigeluth, C.M. \& Keller, J. B. (2009). Understanding instruction. In C. M. Reigeluth \& A. CarrChellman (Eds.), Instructional-design theories and models: Building a common knowledge base (Vol. III) (pp. 27-35). Hillsdale, NJ: Lawrence Erlbaum Associates.

Reigeluth, C. M., Myers, R. D., \& Lee, D. (2017). The learner-centered paradigm of education. In C. M. Reigeluth, B. J. Beatty, \& R. D. Myers (Eds.), Instructional-design theories and models, Volume IV: The learner-centered paradigm of education (Vol. IV, pp. 5-32). New York, NY: Routledge.

Rogers, E. M. (2003). Diffusion of Innovations ( ${ }^{\text {th }}$ Ed.). New York, NY: Free Press.

Rominus, M., Eklund, K., Pesu, L., \& Lyytinen, H. (2019). Supporting struggling readers with digital game-based learning. Educational Technology Research and Development, 67, 639-663. https://doi.org/10.1007/s11423-019-09658-3

Rowland, G. (1993). Designing and instructional design. Educational Technology Research \& Development, 41(3), 79-91.

Rowland, G. (2007). Performance improvement assuming complexity. Performance Improvement Quarterly, 20(2), 117-136.

Shadiev, R., Hwang, W-Y., \& Liu, T-Y. (2018). Investigating the effectiveness of a learning activity supported by a mobile multimedia learning system to enhance autonomous EFL learning in authentic contexts. Educational Technology Research and Development, 66, 893-912. https://doi.org/10.1007/s11423-018-9590-1

Shank, R. C., Berman, T. R., \& Macpherson, K. A. (1999). Learning by doing. In C.M. Reigeluth (Ed.), Instructional-design theories and models: A new paradigm of instructional theory, volume II (pp. 161-181). Hillsdale, NJ: Lawrence Erlbaum Associates.

Solomon, D. L. (2000). Toward a post-modern agenda in instructional technology. Educational Technology Research and Development, 48(4), 5-20.

Solomon, D. L. (2000). Rediscovering post-modern perspectives in IT: Deconstructing Voithofer and Foley. Educational Technology Research and Development, 50(1), 15-20.

Stolterman, E., \& Nelson, H. (2000). The guarantor of design. Proceedings of IRIS 23. Laboratorium for Interaction Technology, University of Trollhättan Uddevalla, 2000. L. Svensson, U. Snis, C. Sørensen, H. Fägerlind, T. Lindroth, M. Magnusson, C. Östlund (eds.)

Tosti, D. T. \& Ball, J. R. (1969). A behavioral approach to instructional design and media selection. AV Communications Review, 17(1), 5-24.

Vandermeer, A. W. (1954). Color vs. black and white in instructional films. Audio-Visual Communications Review, 2(2), 121-134. https://doiorg.proxyiub.uits.iu.edu/10.1007/BF02713271

Wang, F., \& Hannafin, M. (2005). Design-based research and technology-enhanced learning environments. Educational Technology Research and Development, 53(4), 5-23.

Wei, X., Cheng, I., Chen, N. et al. (2020). Effect of the flipped classroom on the mathematics performance of middle school students. Educational Technology Research and Development. https://doi-org.proxyiub.uits.iu.edu/10.1007/s11423-020-09752-x

West, R. E., Thomas, R. A., Bodily, R., Wright, C., \& Borup, J. (2017). An analysis of instructional design and technology departments. Educational Technology Research and

The instructional theory framework appears lost. Isn't it time we find it again? Peter C. Honebein \&

Charles M. Reigeluth. 
Development, 65, 869-888. 10.1007/s11423-016-9490-1

Yanchar, S. C., \& Gabbitas, B. W. (2011). Between eclecticism and orthodoxy in instructional design. Educational Technology Research and Development, 59(3), 383-398. https://doiorg.proxyiub.uits.iu.edu/10.1007/s11423-010-9180-3

You, Y. (1993). What can we learn from chaos theory? An alternative approach to instructional systems design. Educational Technology Research and Development, 41(3), 17-32.

Yuan, J., \& Kim, C. (2018). The effects of autonomy support on student engagement in peer assessment. Educational Technology Research and Development, 66(1), 25-52. https://doi-org.proxyiub.uits.iu.edu/10.1007/s11423-017-9538-x

Zhou, N., \& Yadav, A. (2017). Effects of multimedia story reading and questioning on preschoolers' vocabulary learning, story comprehension and reading engagement. Educational Technology Research and Development, 65, 1523-1545. https://doi.org/10.1007/s11423-017-9533-2 